\title{
A five-year study of a haemophilia reference centre
}

\author{
D. M. RAMSAY AND K. K. KHOO
}

From the Department of Haematology, The Royal Infirmary, Edinburgh

SYNOPSIS Attendances at the Regional Haemophilia Reference Centre in the Edinburgh Royal Infirmary have been analysed over a period of five years from 1969 to 1973 . Of 77 patients registered in 1969, 64 had haemophilia A (factor VIII deficiency) and 13 had haemophilia B (factor IX deficiency). In 1973 the numbers were 68 and 14 respectively. An increased attendance at the Centre from 123 in 1969 to 624 in 1973 was noted. This was due to patients reporting earlier and more frequently for outpatient treatment of haemarthroses which occurred with the greater availability of supplies of factor VIII. The number of admissions for inpatient treatment did not change significantly over the period. Haemarthrosis of the knee was the commonest dominant lesion. The amount of replacement therapy in the form of fresh frozen plasma, cryoprecipitate, antihaemophilic fraction, and factors II, IX, and X concentrate used in the Centre (ie, excluding that used for elective procedures) increased from 2704 donor units in 1969 to 8778 donor units in 1973, the main increase being in cryoprecipitate. The number of factor VIII units used per patient attending per year, for both elective and emergency treatment in haemophiliacs, is recorded and discussed as are its effects on the treatment patterns of patients and the implications for the future.

The management of coagulation disorders has been greatly assisted by the availability of suitable concentrates of blood coagulation factors, and the prompt institution of replacement therapy, for bleeding episodes, has resulted in substantial benefits to the patient with reduction in pain and disability (Green and Smith, 1972). The establishment of haemophilia reference centres for the diagnosis and treatment of coagulation disorders, as initially advocated by the Medical Research Council in 1955, has facilitated the realization of the above aim. The importance of such centres has been emphasized subsequently (MacFarlane and Biggs, 1966; Dalrymple-Champneys et al, 1967; Rizza, 1970).

This paper describes the Edinburgh Haemophilia Reference Centre and the changing pattern of attendance and treatment during five years of its operation. The Centre is located in the Edinburgh Royal Infirmary within ready access to the Haematology Department, the Regional Blood Transfusion Centre, and the medical, dental, and orthopaedic wards. Its functions follow the guidelines of the memorandum on the functions of haemophilia centres issued by the Department of Health and Social Security in 1968 and may be summarized as follows:

Received for publication 24 March 1975. (a) to provide a full diagnostic service for patients with suspected haemostatic disorders and to issue appropriate identification cards;

(b) to provide continuous outpatient facilities for patients with chronic haemostatic disorders such as haemophilia A or haemophilia B so that patients do not require to be admitted via the general practitioner or the accident and emergency services and early effective treatment can be given;

(c) to educate hospital staff and patients in the relevant aspects of haemostasis and teach suitable patients to give themselves intravenous infusions in preparation for home treatment or prophylaxis where indicated;

(d) to act as a liaison centre for the social and welfare services available to this class of handicapped patients;

(e) to collaborate with other centres in research and in the exchange of relevant information.

\section{Patients and Methods}

The study was carried out on all haemophiliacs who attended the Edinburgh Haemophilia Reference Centre on an outpatient basis, although some were subsequently admitted to the ward as inpatients. The records of each attendance at the Centre or admission to the ward included the following details : 
name of patient, diagnosis of bleeding disorder, bleeding source or, in the case of haemarthropathy, the joint or joints affected, blood components used for replacement therapy, as well as the amount given.

Patients seen by appointment at the Haematology Department or at clinics, those admitted for dental surgery or elective operations, and others admitted to the ward through the Accident and Emergency Department are not included in this study. Very few acutely bleeding patients from those known to have haemostatic disorders were admitted through Accident and Emergency, but a large number of consultations was undertaken at the Haematology Clinic, eg, for general advice, assessment of joint function, and dental assessment.

\section{Results}

There were 64 registered patients with haemophilia A (factor VIII deficiency) and 13 with haemophilia B or Christmas disease (factor IX deficiency) in the south-east of Scotland in 1969, rising to 68 and 14 registered patients respectively in 1973 (table I). These numbers, in a population of just under 1200000 , indicated the prevalence of haemophilia to be about 6 per 100000 of the population and the disease to be five times more common than Christmas disease. Table I also shows the breakdown of cases into the three grades of severity of the two diseases, namely severe (factor VIII or factor IX level $1 \%$ or less), moderate (factor VIII or factor IX level between 1 and $5 \%$ ), and mild (factor VIII or factor IX level between 5 and $25 \%$ ).

Numbers of patients attending the Centre, for each grade of severity of the two diseases, are shown as proportions of the total numbers in each group. Table I shows this both for those managed as outpatients and for those admitted as inpatients. Table II shows a breakdown of the total yearly number of attendances for the two classes, according to the dominant causative lesion. The numbers of those who required to be admitted remained constant over the period studied or possibly fell slightly in the last two years. However, for those treated as outpatients, the average number of attendances per patient on the haemophilia register rose from less than one in the first year to seven in the fifth year.

The amounts of material used for emergency and elective component replacement therapy are shown in table III for both haemophilia A and haemophilia B. The total donor equivalents of this replacement

\begin{tabular}{|c|c|c|c|c|c|c|c|c|c|c|c|c|c|c|c|c|c|c|c|c|}
\hline \multirow[t]{2}{*}{ Year } & \multicolumn{10}{|c|}{ Haemophilia A } & \multicolumn{10}{|c|}{ Haemophilia B } \\
\hline & $\begin{array}{l}\text { Total } \\
\text { Patients }\end{array}$ & Mild & $O P$ & $I P$ & $\begin{array}{l}\text { Moder- } \\
\text { ate }\end{array}$ & $O P$ & $I P$ & Severe & $O P$ & $I P$ & $\begin{array}{l}\text { Total } \\
\text { Patients }\end{array}$ & Mild & $O P$ & IP & $\begin{array}{l}\text { Moder- } \\
\text { ate }\end{array}$ & $O P$ & $I P$ & Severe & $O P$ & $\boldsymbol{I P}$ \\
\hline $\begin{array}{l}1969 \\
1970 \\
1971 \\
1972 \\
1973\end{array}$ & $\begin{array}{l}64 \\
61 \\
68 \\
68 \\
68\end{array}$ & $\begin{array}{l}20 \\
20 \\
21 \\
21 \\
21\end{array}$ & $\begin{array}{l}0 \\
2 \\
1 \\
3 \\
1\end{array}$ & $\begin{array}{l}3 \\
1 \\
4 \\
2 \\
1\end{array}$ & $\begin{array}{l}18 \\
17 \\
23 \\
23 \\
24\end{array}$ & $\begin{array}{r}5 \\
5 \\
12 \\
12 \\
16\end{array}$ & $\begin{array}{r}9 \\
6 \\
14 \\
10 \\
10\end{array}$ & $\begin{array}{l}26 \\
24 \\
24 \\
24 \\
23\end{array}$ & $\begin{array}{r}8 \\
9 \\
13 \\
18 \\
18\end{array}$ & $\begin{array}{l}12 \\
14 \\
14 \\
18 \\
12\end{array}$ & $\begin{array}{l}13 \\
11 \\
11 \\
13 \\
14\end{array}$ & $\begin{array}{r}10 \\
8 \\
8 \\
9 \\
10\end{array}$ & $\begin{array}{l}0 \\
0 \\
0 \\
2 \\
4\end{array}$ & $\begin{array}{l}4 \\
0 \\
0 \\
0 \\
1\end{array}$ & $\begin{array}{l}2 \\
2 \\
2 \\
3 \\
3\end{array}$ & $\begin{array}{l}1 \\
1 \\
1 \\
1 \\
1\end{array}$ & $\begin{array}{l}2 \\
1 \\
1 \\
2 \\
1\end{array}$ & $\begin{array}{l}1 \\
1 \\
1 \\
1 \\
1\end{array}$ & $\begin{array}{l}1 \\
1 \\
1 \\
1 \\
1\end{array}$ & $\begin{array}{l}1 \\
1 \\
1 \\
0 \\
0\end{array}$ \\
\hline
\end{tabular}

Table I Patients registered and numbers treated-outpatients $(O P)$ and inpatients (IP)

\begin{tabular}{|c|c|c|c|c|c|c|c|c|c|c|}
\hline \multirow[t]{2}{*}{ Dominant Lesion } & \multicolumn{2}{|c|}{1969} & \multicolumn{2}{|c|}{1970} & \multicolumn{2}{|c|}{1971} & \multicolumn{2}{|c|}{1972} & \multicolumn{2}{|c|}{1973} \\
\hline & $I P$ & $O P$ & IP & $O P$ & $I P$ & $O P$ & $I P$ & $O P$ & $I P$ & $O P$ \\
\hline Knee joint & 9 & 18 & 13 & 67 & 4 & 81 & 19 & 163 & 5 & 189 \\
\hline Ankle joint & 2 & 13 & 7 & 11 & 5 & 27 & 9 & 74 & 5 & 133 \\
\hline Hip joint & 5 & 0 & 4 & 1 & 3 & 4 & 4 & 10 & 7 & 36 \\
\hline Elbow joint & 2 & 9 & 2 & 14 & 5 & 10 & 2 & 44 & 1 & 96 \\
\hline Wrist joint & 1 & 2 & 1 & 2 & 1 & 11 & $\mathbf{0}$ & 4 & 0 & 7 \\
\hline Shoulder joint & 4 & 9 & 5 & 9 & 2 & 17 & 1 & 17 & 1 & 18 \\
\hline Joints of hand & 1 & 1 & $\mathbf{0}$ & 0 & 1 & 3 & 1 & 9 & 1 & 13 \\
\hline Joints of foot & 0 & 1 & 1 & 4 & 1 & 2 & $\mathbf{0}$ & 15 & $\mathbf{0}$ & 22 \\
\hline Soft tissue bleeds & 9 & 9 & 10 & 8 & 9 & 3 & 8 & 34 & 10 & 40 \\
\hline Retroperitoneal bleeds & 1 & $\mathbf{0}$ & 2 & $\mathbf{0}$ & 6 & 3 & 2 & 1 & 6 & 1 \\
\hline Lip. tongue, and gum bleeds & 8 & 2 & 7 & $\mathbf{0}$ & 8 & 2 & 8 & 11 & 3 & 16 \\
\hline Epistaxis & 3 & $\mathbf{0}$ & 4 & $\mathbf{0}$ & 6 & 0 & 1 & 2 & $\mathbf{0}$ & $\mathbf{0}$ \\
\hline Gastrointestinal bleeds & 4 & $\mathbf{0}$ & 1 & $\mathbf{0}$ & 5 & 0 & 2 & $\mathbf{0}$ & 5 & 0 \\
\hline Haematuria & 5 & 4 & 1 & 1 & 6 & $\mathbf{0}$ & $\mathbf{0}$ & 4 & 5 & 4 \\
\hline Intracerebral bleeds & 1 & 0 & 0 & 0 & 0 & 0 & 0 & 0 & 0 & 0 \\
\hline Totals & 55 & 68 & 58 & 117 & 62 & 163 & 57 & 388 & 49 & 575 \\
\hline
\end{tabular}

Table II Breakdown of total yearly inpatient (IP) and outpatient (OP) treatments 


\begin{tabular}{|c|c|c|c|c|c|c|c|c|c|c|c|c|c|c|c|c|}
\hline \multirow[t]{2}{*}{ Year } & \multicolumn{3}{|c|}{$\begin{array}{l}\text { Cryoprecipitate Packs } \\
\text { (single donor units) }\end{array}$} & \multicolumn{3}{|c|}{$\begin{array}{l}\text { Antihaemophilic } \\
\text { Fraction Units }{ }^{1}\end{array}$} & \multicolumn{3}{|c|}{$\begin{array}{l}\text { Fresh Frozen Plasma } \\
(400 \mathrm{ml} \text { units })^{2}\end{array}$} & \multicolumn{3}{|c|}{$\begin{array}{l}\text { Factors } I I, I X, X \\
\text { Concentrate } \\
(10 \text { ml units })^{3}\end{array}$} & \multicolumn{4}{|c|}{ Total Donor Units } \\
\hline & $O P$ & $I P$ & $D E$ & $O P$ & $I P$ & $D E$ & $O P$ & $I P$ & $D E$ & $O P$ & $I P$ & $D E$ & $O P$ & $I P$ & $D E$ & Total \\
\hline $\begin{array}{l}1969 \\
1970 \\
1971 \\
1972 \\
1973\end{array}$ & $\begin{array}{r}0 \\
110 \\
965 \\
2266 \\
4273\end{array}$ & $\begin{array}{r}0 \\
0 \\
547 \\
673 \\
1891\end{array}$ & $\begin{array}{r}0 \\
0 \\
24 \\
519 \\
1015\end{array}$ & $\begin{array}{r}0 \\
0 \\
24 \\
267 \\
95\end{array}$ & $\begin{array}{r}244 \\
72 \\
255 \\
141 \\
272\end{array}$ & $\begin{array}{r}45 \\
139 \\
96 \\
219 \\
97\end{array}$ & $\begin{array}{r}119 \\
295 \\
31 \\
0 \\
0\end{array}$ & $\begin{array}{r}441 \\
404 \\
31 \\
21 \\
8\end{array}$ & $\begin{array}{r}208 \\
100 \\
0 \\
0 \\
0\end{array}$ & $\begin{array}{r}0 \\
0 \\
15 \\
119 \\
62\end{array}$ & $\begin{array}{r}40 \\
0 \\
25 \\
0 \\
70\end{array}$ & $\begin{array}{r}0 \\
0 \\
0 \\
8 \\
43\end{array}$ & $\begin{array}{r}238 \\
700 \\
1216 \\
4225 \\
5029\end{array}$ & $\begin{array}{l}2466 \\
1240 \\
2214 \\
1561 \\
3749\end{array}$ & $\begin{array}{r}686 \\
1034 \\
700 \\
1857 \\
1726\end{array}$ & $\begin{array}{r}3390 \\
2974 \\
4130 \\
7643 \\
10504\end{array}$ \\
\hline
\end{tabular}

Table III Materials used yearly for replacement therapy-outpatient $(O P)$, inpatient (IP), and dental and elective surgery $(D E)$

11 Antihaemophilic fraction unit is obtained from six blood donations $2400 \mathrm{ml}$ of fresh frozen plasma is obtained from two blood donations

$\mathbf{s} 10 \mathrm{ml}$ of factors II, IX, and X concentrate is prepared from the equivalent of three blood donations

\begin{tabular}{|c|c|c|c|c|c|}
\hline Year & $\begin{array}{l}\text { Cryoprecipitate Packs } \\
\text { (equivalent factor } \\
\text { VIII units) })^{1}\end{array}$ & $\begin{array}{l}\text { Antihaemophilic } \\
\text { Fraction (equivalent } \\
\text { factor VIII units) }\end{array}$ & $\begin{array}{l}\text { Fresh Frozen Plasma } \\
\text { (equivalent factor } \\
\text { VIII units) }\end{array}$ & $\begin{array}{l}\text { Total Factor VIII } \\
\text { Units }^{4}\end{array}$ & $\begin{array}{l}\text { Total Factor VIII } \\
\text { L'nits/Patient } \\
\text { attending } 1 \text { Year }\end{array}$ \\
\hline $\begin{array}{l}1969 \\
1970 \\
1971 \\
1972 \\
1973\end{array}$ & $\begin{array}{rr} & 0 \\
12320 \\
166544 \\
387296 \\
804408\end{array}$ & $\begin{array}{r}115600 \\
84400 \\
150000 \\
250800 \\
185600\end{array}$ & $\begin{array}{r}159300 \\
178800 \\
14700 \\
2100 \\
2400\end{array}$ & 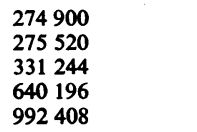 & $\begin{array}{r}9163 \\
10204 \\
8493 \\
14549 \\
23628\end{array}$ \\
\hline
\end{tabular}

Table IV Materials and equivalent factor VIII units used yearly for all forms of replacement therapy in haemophiliacs

${ }^{1}$ One single donor unit of cryoprecipitate is estimated to contain 112 factor VIII units

One antihaemophilic fraction unit contains $\mathbf{4 0 0}$ factor VIII units

'One $400 \mathrm{ml}$ fresh frozen plasma unit contains 300 factor VIII units

'One unit of factor VIII is the amount of factor VII contained in $1 \mathrm{ml}$ of freshly pooled plasma

therapy rose from 3390 in 1969 to 10504 in 1973. Most of the rise was in outpatient therapy; however, a significant rise in the number of donor equivalents, used for patients admitted to the ward from the Centre, was recorded in the last year. The number of factor VIII units used per patient attending per year, whether on an outpatient or emergency or elective inpatient basis, has also been calculated (table IV), assuming that one factor VIII unit is the amount of factor VIII in $1 \mathrm{ml}$ of fresh pooled plasma.

\section{Discussion}

The prevalence of haemophilia $A$ in the south-east of Scotland, 6 per 100000 of the population, was higher than the estimated 3-4 per 100000 for the population of Britain as a whole (MacFarlane, 1966). Also, unexpectedly large numbers of patients with haemophilia B were registered in the south-east of Scotland, the relative frequency of haemophilia A to haemophilia $B$ being $5: 1$. This ratio differs markedly from that of 10:1 given by MacFarlane (1966) for the population of Britain as a whole. The high prevalence of haemophilia B was due to a large number of mild cases belonging to several related families in the area. Among the haemophilia A patients, the numbers of mild, moderate, and severe cases were approximately the same. It is noted that patients with moderate haemophilia were almost as frequent attenders as patients with the severe form of the disease. This could be explained by the fact that a large proportion of the moderately affected were growing children or young adults with factor VIII levels at the lower end of the moderate range, whereas most of the severely affected patients were adults who had learned to avoid bleeding episodes.

Haemarthropathy was by far the most frequent reason for attendance (table II) and, in the majority of cases, was managed on an outpatient basis. As previously reported by Stuart et al (1966) and Trueta (1966), haemarthrosis of the knee joint was the most common while the hip joint was rarely affected. When bleeding occurred from a source other than a joint, the patient was more likely to be admitted.

Table II also shows the steep rise in outpatient attendances over the five years. The following factors were thought to account for this: patients reported earlier and more frequently for treatment 


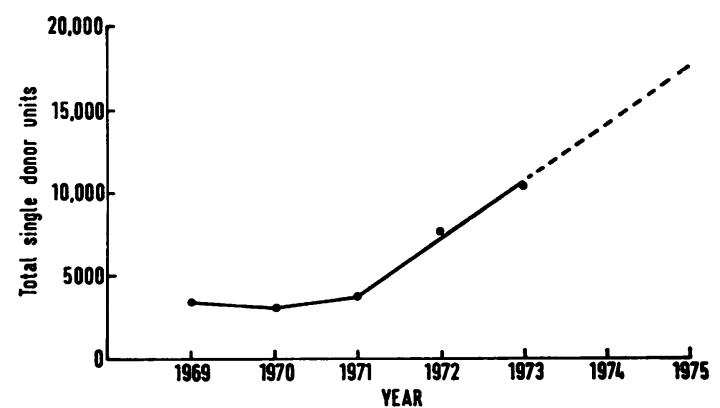

Fig 1 Total number of donor units used in Reference Centre and for elective treatment

of bleeding lesions, increased supplies of cryoprecipitate were available from 1971 onwards, and, lastly, patients began to live fuller, more active lives as a result of potent, easily administered therapautic materials becoming available. It was hoped that early treatment might reduce inpatient admissions by controlling the bleeding episode shortly after its onset. However, so far, the fall in numbers of patients requiring admission to hospital from the Centre has not been significant.

Since cryoprecipitate became more readily available in 1971, the amount of replacement therapy used for patients attending the Reference Centre and for patients admitted electively has risen steeply (fig 1), and a ceiling for quantities required has not yet been reached. An attempt has been made to forecast future requirements by extending the curve of total donor units, used for all emergency and elective treatment, forward in time (fig 1). Assuming there is no change in the volume of plasma used to make one pack of cryoprecipitate and the same recovery of factor VIII, ie, $50 \%$, is achieved in the material supplied, the total number of donor units estimated for 1974 is 14000 and for 1975 it is 17500 .

Biggs (1974) has suggested that requirements for replacement therapy should be assessed on a basis of numbers of factor VIII units used per patient per year whether treated on an outpatient or inpatient basis. Factor IX units are not counted as the blood used to make factor IX concentrate is also used to make factor VIII. This method of assessment is particularly useful for centres where there are large numbers of visiting haemophiliacs and where a considerable proportion of those registered attend the Centre only for major bleeds or for operative procedures. Figure 2 shows the rise in factor VIII units per patient attending per year in the Edinburgh Haemophilia Reference Centre, and extrapolation of the curve in fig 2 shows that 29000 units will be required in 1974 and 36000 units in 1975.

The increased use of replacement therapy in 1972 and 1973 was not associated with an increase in either jaundice or the number of patients who developed inhibitors. Although the total number of patients with inhibitors rose from two in 1969 to seven in 1973, only one new case developed after 1971 (table V). The probable explanation for this was that those patients most likely to develop inhibitors would already have done so by 1970 . The decrease in serum hepatitis was almost certainly due to the practice of testing blood donors for serum hepatitis-associated antigen and antibody. This has been carried out in the Edinburgh Regional Transfusion Service since February 1971.

A final benefit of the Centre was the education of patients in being able to manage their own intra-

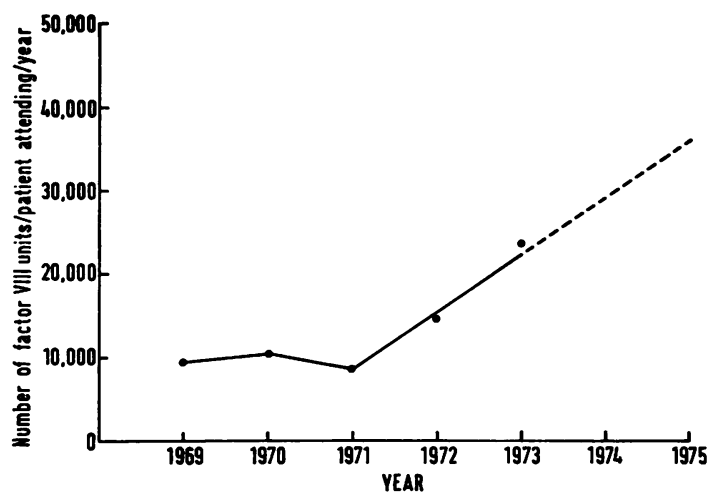

Fig 2 Number of factor VIII units used per patient attending per year both at Reference Centre and for elective treatment

\begin{tabular}{llll}
\hline Year & $\begin{array}{l}\text { Incidence of New Inhibitors } \\
\text { in Patients }\end{array}$ & $\begin{array}{l}\text { Total No of Patients } \\
\text { with Inhibitors }\end{array}$ \\
\hline 1969 & 1 & 2 & Occurrence of Jaundice \\
1970 & 4 & 5 & 0 \\
1971 & 1 & 6 & 1 \\
1972 & 0 & 6 \\
1973 & 1 & 7 \\
\hline
\end{tabular}

Table V Occurrence of inhibitors and jaundice in patients with haemophilia and Christmas disease 
venous therapy. Most of the regular attenders over the age of 14 are able to give themselves antihaemophilic fraction or cryoprecipitate by drip infusion or intravenous injection in preparation for self treatment at home, if indicated, and several patients, who live at a distance from the Centre are already administering home treatment or prophylaxis in the case of haemophilia B. The dried products, such as antihaemophilic fraction and factors II, IX, and $\mathrm{X}$ concentrate, which are stable and can be stored at $4^{\circ} \mathrm{C}$, have been of special benefit in this respect. No significant instances of haematomata have been attributed to patients administering their own therapy, and both patients and staff have noticed that 'preservation of veins' has been improved in a number of the patients concerned.

We gratefully acknowledge the guidance of $\mathrm{Dr} \mathrm{S}$. H. Davies, consultant haematologist, in the preparation of this paper. We also wish to thank Dr R. A. Cumming, ex-director of the Edinburgh and SouthEast Scotland Regional Blood Transfusion Service, and Dr J. D. Cash, the present director, for the supply of blood products used in this study.

\section{References}

Biggs, R. (1974). Personal communication.

Dalrymple-Champneys, W., Hunter, J. R., and Polton, K. R. (1967). Treatment of haemophilia. Brit. med. J., 2, 440.

Green, D. and Smith, N. J. (1972). Hemophilia: current concepts in management. Med. Clin. N. Amer., 56, 105-117.

Department of Health and Social Security (1968). Arrangements for the Care of Persons suffering from Haemophilia and Related Diseases. H.M. (68) 8, London.
MacFarlane, R. G. (1966). In Treatment of Haemophilia and Other Coagulation Disorders, edited by R. Biggs and R. G. MacFarlane, p. 1. Blackwell Scientific Publications, Oxford.

MacFarlane, R. G. and Biggs, R. (1966). In Treatment of Haemophilia and Other Coagulation Disorders, edited by R. Biggs and R. G. MacFarlane, p. 324. Blackwell Scientific Publications, Oxford.

Biggs, R. (1974). Haemophilia and its related conditions: a brief guide to diagnosis and treatment. Memor. med. Res. Coun. (Lond.), No. 44, iii.

Rizza, C. R. (1970). The management of haemophilia. The Practitioner, 204, 763-772.

Rizza, C. R. and Biggs, R. (1971). Haemophilia today. Brit. J. Hosp. Med., 6, 343-356.

Stuart, J., Davies, S. H., Cumming, R. A., Girdwood, R. H., and Darg, A. (1966). Haemorrhagic episodes in haemophilia: a five year prospective study. Brit. med. J., 2, 1624-1626.

Trueta, J. (1966). In Treatment of Haemophilia and Other Coagulation Disorders, edited by R. Biggs and R. G. MacFarlane, p. 279. Blackwell Scientific Publications, Oxford.

\section{Addendum}

Although the number of cryoprecipitate packs used for outpatients at the Centre rose from 4273 in 1973 to 4603 in 1974, the amounts of cryoprecipitate and AHF used for inpatient treatment, including elective operations, fell by an amount equivalent to 1950 donor units so that the total donor units used if 1974 was 9304 as compared with 10504 in 1973 . The predicted rise in total donor units required in 1974, as shown in fig 1 , has not been borne out, and this may signify a lessening of increase in demand for replacement therapy. 